\title{
Free Cash Flow, Agency Costs, and the Affordability Method of Advertising Budgeting
}

The allocation of excess cash has long been recognized in the finance literature as an important aspect of the basic agency conflict between managers and owners. In the advertising budgeting context, marketing scholars report that firms possessing high levels of cash tend to spend more on advertising than what seems necessary or desirable. Indeed, this positive link between excess cash and advertising expenditures constitutes a part of what is commonly referred to as the affordability method of advertising budgeting. Surprisingly, there has been little research that attempts to view this association as a manifestation of agency costs. Therefore, in this article, the authors examine whether agency costs, as measured by managerial ownership, moderate the relationship between excess cash and advertising expenditures. On the basis of received theory, the authors conceptualize that agency costs will first decrease, then increase, and then decrease again with the level of managerial ownership. Accordingly, the authors hypothesize and find that the fraction of incremental earnings reinvested in advertising follows the same pattern in managerial ownership. These findings support the notion that the use of the affordability method is driven, in part, by agency costs. The authors conclude by discussing the theoretical and managerial implications of the findings.

t has long been recognized in the finance literature that the allocation of free cash flow is an important aspect of the basic conflict of interest between managers and owners (Jensen 1986).' Specifically, free cash flow tempts managers to expand the size of the firm, thereby increasing managers' control and personal remuneration even though such an action may decrease the overall value of the firm. Marketing scholars have also identified a similar phenomenon in the allocation of excess cash to advertising. Tellis (1998, p. 396), for example, writes, "when firms are flush with cash, they tend to spend liberally on advertising, even beyond what seems necessary or desirable." This link between excess cash and advertising budgets constitutes one part of what is generally known in the literature as the "affordability" method of advertising budgeting. However, to date, there has been no attempt to view the use of this heuristic as a manifestation of the agency costs between owners and managers. ${ }^{2}$ This research is an attempt to explore this connection.

Why does free cash flow tempt managers to expand the size of the firm beyond the optimal point? Jensen (1986)

'Formally, free cash flow is defined as cash in excess of that required to fund all positive net present value projects. Loosely, free cash tlow may be considered analogous to excess cash on hand.

2 Agency costs refer to the sum of the costs of designing, implementing, and maintaining the appropriate control system within organizations and the residual loss resulting from the difficulty of solving control problems completely (Jensen and Meckling 1992).

Kissan Joseph is Associate Professor of Marketing and Charles Oswald Research Fellow, and Vernon J. Richardson is Assistant Professor of Business and KPMG Peat Marwick Faculty Scholar, School of Business, University of Kansas. The authors are listed in alphabetical order, both contributed equally. The authors thank the four anonymous $J M$ reviewers for several constructive and insightful comments on previous versions of the article. notes that growth typically increases managers' power by increasing the resources under their control. Moreover, growth is also directly related to managerial compensation because changes in compensation are often positively related to growth in sales. Finally, the tendency of firms to reward managers through promotion rather than year-toyear bonuses also creates a strong organizational bias toward growth in order to supply the new positions that such promotion-based reward systems typically require.

In the context of advertising budgeting, free cash flow may give rise to a scenario in which managers reinvest discretionary dollars into advertising with a view to expand sales, even if these investments are not cost effective. Given the economic significance of advertising budgets to both the economy and individual firms, ${ }^{3}$ our primary objective in this research is to investigate whether the propensity to invest excess cash into advertising is driven, in part, by agency costs in the owner-manager relationship. As such, our research may also be viewed as an investigation into the use of the affordability method in situations in which firms have excess cash.

The mere existence of a positive link between free cash flow and advertising budgets does not imply inefficient use of monies. There may be sound economic reasons for such a link. Nerlove and Arrow (1962), for example, demonstrate that under conditions of constant price and advertising elasticities, the optimal advertising expenditures may well be a fixed percentage of sales. To

${ }^{3}$ Nationally, companies in the United States invested approximately $\$ 200$ billion on advertising in 1998 . This amounts to more than $\$ 700$ for each of the nearly 270 million men, women, and children in the United States. In addition, several U.S. firms invest more than $\$ 1$ billion in domestic advertising. Even the U.S. government advertises to the tune of $\$ 670$ million annually (Czinkota 1999, p. 431). 
the extent that sales and free cash flow are correlated, it may indeed be optimal to invest excess cash into advertising. Another reason for the positive link between free cash flow and advertising budgets may be found in the inherent uncertainty about the advertising-sales relationship. In this connection, it is important to recognize that setting the advertising budget in order to achieve the maximum yield is an immensely difficult problem (Bigne 1995). In general, it is challenging to determine the sales response to advertising. Moreover, many studies show little or no impact of advertising on sales in the short run (Eastlack and Rao 1989). Given a lack of understanding of the advertising-sales relationship, a strategy of allocating some fraction of discretionary dollars toward advertising could be akin to purchasing insurance: More is purchased when the firm has a greater amount of discretionary dollars and, consequently, a lower cost of capital. Given these arguments for a positive link between free cash flow and advertising, our incremental contribution is to demonstrate that this association is moderated by agency costs.

We operationalize our emphasis on agency costs by focusing on a key agency variable, namely, the extent of managerial ownership. Indeed, it is well documented in the finance literature that ownership can prove to be a valuable tool in reducing agency costs between managers and owners (Jensen and Meckling 1976). Specifically, ownership motivates managers to use their decision rights efficiently because they bear the rewards and punishments of their actions. Previous research, however, suggests that agency costs need not decrease uniformly with the level of management ownership. Morck, Shleifer, and Vishny (1988), for example, posit that agency costs will first decrease, then increase, and finally decrease again with the level of managerial ownership. Accordingly, they hypothesize that measures of firm valuation will first increase, then decrease, and finally increase again with the proportion of managerial ownership.

Briefly, the rationale for these counterintuitive expectations is as follows: Morck, Shleifer, and Vishny (1988) suggest that ownership first improves firm performance because of the convergence in interests between managers and owners. That is, providing managers with a claim on the firm aligns their goals with those of owners and motivates them to take actions that are value maximizing. However, this beneficial effect of ownership is soon mitigated by an adverse effect. Specifically, as managers begin to hold a substantial fraction of the firm's equity, they become entrenched; this entrenchment, in turn, enables them to pursue non-value-maximizing behaviors without being disciplined by the market. Thus, in this range, firm value decreases with ownership as the adverse effects of entrenchment become increasingly pronounced. This does not imply that convergence effects are absent here-they continue to operate but are dominated by entrenchment effects. Finally, as management ownership increases further, the high level of ownership gives rise to a situation in which convergence effects dominate; consequently, in this region, firm value again increases with ownership.
We follow Morck, Shleifer, and Vishny (1988) and specify that agency costs will vary nonmonotonically with the level of managerial ownership. As do Morck, Shleifer, and Vishny, we measure managerial ownership by the extent of firm ownership among members of the board. We then examine whether the fraction of earnings reinvested in advertising is moderated by the level of ownership in a sample of firms culled from the Compustat database. As hypothesized, we find that ownership by board members has a systematic and economically significant impact on the fraction of earnings that is reinvested in advertising. Moreover, we also find nonmonotonic effects, which suggest the same interplay of convergence and entrenchment effects demonstrated by Morck, Shleifer, and Vishny (1988). We therefore conclude that agency costs play an important role in the reinvestment of excess cash to advertising.

In a broader context, our work explicitly highlights one specific mechanism through which agency problems degrade firm value. Although agency problems have been well documented in the marketing literature (see, e.g., Bergen, Dutta, and Walker 1992), there is little research on the specific mechanisms through which this value dissipation occurs. Our work suggests that the misallocation of excess monies to advertising is one specific route through which agency costs degrade firm value. As such, the current investigation also deepens the understanding of alternative mechanisms through which agency costs affect firm value.

The rest of the article is organized in the following manner: In the next section, we provide a brief review of the literature. We then describe our hypothesis and model. Next, we describe our sample, measures, and estimation equation. Finally, we present our empirical findings and conclude by discussing the contributions and limitations of our research endeavor.

\section{Literature Review}

Our literature review is divided into three parts. In the first, we review the impact of agency costs on the allocation of discretionary monies. We then examine how agency costs vary with a key variable of interest, namely, managerial ownership. Specifically, we describe in detail the convergence and entrenchment effects identified in prior work, because it has a direct bearing on our research. Finally, we provide a general overview of advertising budgets. This overview provides the appropriate context and aids in the development of our hypothesis

\section{Impact of Agency Costs on the Allocation of Free Cash Flow}

The finance literature has long recognized the impact of agency costs on the allocation of discretionary monies (the so-called free cash flow hypothesis). A large strand of research examines the relationship between agency costs and financial structure. Jensen (1986) posits that leveraged buyout activities are one way of controlling free cash flow because the debt incurred in such transactions forces managers to disgorge excess cash rather than direct it to unprofitable opportunities. Evidence supporting the free cash flow motivation for financial restructuring has been provided by 
many authors (Gibbs 1993; Griffin 1988; Gupta and Rosenthal 1991; Lehn and Poulsen 1989; Loh 1992; Moore, Christensen, and Roenfeldt 1989).

In the accounting literature, Gul and Tsui (1998) examine the relationship between the amount of free cash flow and audit fees. They hypothesize that because managers will likely engage in non-value-maximizing activities while allocating free cash flow, auditors' assessment of the inherent risk and, in turn, the audit effort will increase with the amount of free cash flow possessed by the firm. Gul and Tsui therefore postulate a positive relationship between high levels of free cash flow and audit fees. As expected, they find this association in their data set.

The free cash flow hypothesis has also been tested in the context of the issue of equity. Mann and Sicherman (1991) hypothesize that shareholders will respond negatively to equity issue announcements because they expect management to misuse such nonbonded funds. Furthermore, they also expect shareholder response to be moderated by the track record of management with respect to previous equity issues. Finally, Wells, Cox, and Gaver (1995) compare the level of cash flow for mutual insurers and stock insurers and find that the latter possess greater levels of cash flow. Wells, Cox, and Gaver posit that management at these firms is able to hoard cash because it is governed by fewer monitoring and control mechanisms. This hoarding of cash, though non-value maximizing, provides management with the important benefit of avoiding the scrutiny of the capital markets when the firm requires additional capital.

In summary, there is a vast body of research in accounting and finance that convincingly demonstrates that agency costs play an important role in the allocation of discretionary monies. As is evident from this brief review, researchers have examined the impact of agency costs on various topics, such as financial structure, audit fees, response to equity announcements, and the level of free cash flow. This stream of research enables us to conceptualize the impact of agency costs on the allocation of discretionary monies in an important marketing context, namely, advertising budgeting.

\section{Agency Costs as a Function of the Level of Firm Ownership by Board Members}

As mentioned previously, management ownership may serve as a useful mechanism to reduce agency costs and bring about goal alignment. As their stakes in the company rise, managers bear a larger portion of the cost of pursuing non-value-maximizing objectives; consequently, they will increasingly pursue value-maximizing objectives. It is important to recognize that small levels of firm ownership by managers can prove to be significant when viewed as a proportion of total managerial compensation. Thus, even small levels of firm ownership can prove to be beneficial. Overall, this goal alignment through ownership is referred to as the convergence-of-interests effect.

Many scholars have pointed out limitations in the ability of managerial ownership to bring about goal alignment (Demsetz 1983; Fama and Jensen 1983). These researchers suggest that when a manager owns only a small stake, market discipline (e.g., the managerial labor market [Fama
1980], the product market [Hart 1983], and the market for corporate control [Jensen and Ruback 1983]) may indeed force the manager toward value maximization. However, managers who control a substantial fraction of the firm's equity may have enough voting power and/or influence to indulge in their preference for non-value-maximizing behavior. Examples of such non-value-maximizing behavior include empire building, expensive corporate offices, lavish company trips, purchase of high-priced paintings, installation of a fleet of business jets, and so forth. This socalled entrenchment effect, arising from relatively unfettered power, suggests that ownership may not always lead to goal alignment and value maximization. 4

On the basis of these considerations, Morck, Shleifer, and Vishny (1988) empirically examine how these opposing effects resolve in the case of firm performance. They suggest that whereas the convergence-of-interests effects should increase uniformly over the range of ownership, entrenchment effects may surface only after some threshold level of ownership. In particular, they posit that entrenchment effects may begin to surface above some critical level of ownership and increase to attain their peak well before majority ownership (for a pictorial representation of these effects, see Figure 1). Now, as ownership increases from $0 \%$ to $100 \%$, the relative influences of convergence and entrenchment are as follows: Initially, entrenchment effects are absent and increases in managerial ownership give rise to an increase in convergence effects. As ownership increases further, however, entrenchment effects begin to surface. In this range, as entrenchment grows, managers can increasingly indulge in non-value-maximizing behaviors. Finally, as ownership increases even further, convergence effects again begin to dominate because the high level of ownership causes man-

4 In this connection, Weston (1979) reports that no firm in which insiders owned more than $30 \%$ has ever been acquired in a hostile takeover. This suggests that managers who control a substantial portion of the firm's equity may be relatively free from the discipline of the market.

\section{FIGURE 1}

Relative Strengths of Convergence and Entrenchment as a Function of Managerial Ownership

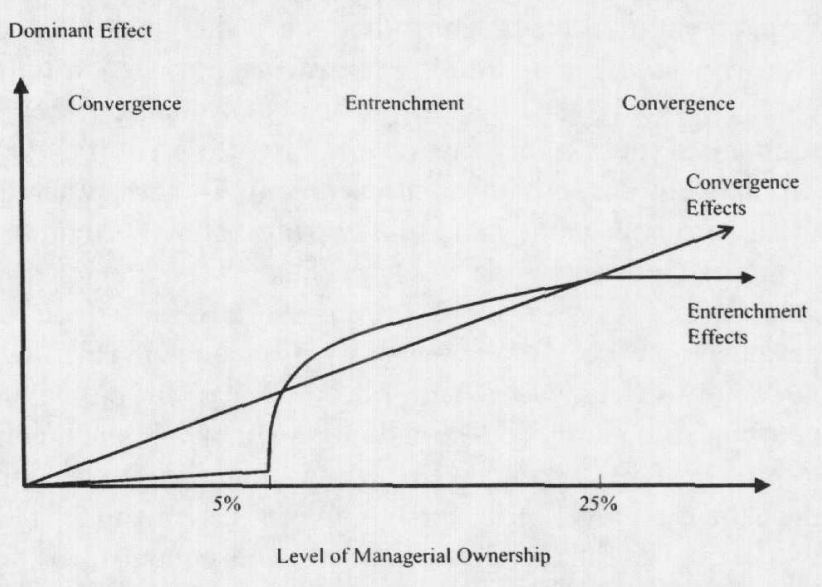


agers to fully bear the costs of any non-value-maximizing action. For these reasons, firm value, as measured by Tobin's $\mathrm{Q}$ and profit rate, ${ }^{5}$ should first rise to reflect the impact of convergence, then decrease as entrenchment effects come into play, and finally increase again as convergence effects dominate. In their empirical work, Morck, Shleifer, and Vishny find these effects, and the results are robust across both measures of firm performance. Figure 2 displays their findings with respect to Tobin's $Q$.

\section{Advertising Budgets}

It is generally recognized in the marketing literature that many firms overspend with respect to advertising. In a wellknown article titled, "Are You Overadvertising?" Aaker and Carman (1982) review the findings from both field experiments and econometric studies. They conclude that, in general, firms are overadvertising and suggest that several advertisers should experiment with reduced advertising expenditures. They also suggest that the reward structure at advertising firms is likely to be a key driver behind this observed pattern of overadvertising.

More recently, Prasad and Sen (1999) review the academic literature since 1982 and examine whether there is evidence of systematic overadvertising. Specifically, they review the articles that have appeared in the years following Aaker and Carman's article. Prasad and Sen (1999) report that though the econometric studies yield mixed findings, the evidence from field experiments points to continued overadvertising by firms. They also suggest that incentive structure, among other factors, could likely contribute to the excessive spending with respect to advertising.

5Formally, Tobin's $Q$ is measured as the ratio of the market value of a firm (or the weighted average firm in the financial markets) to the net replacement cost of firm assets (Wernerfelt and Montgomery 1988).

\section{FIGURE 2}

The Relationship Between Ownership Level and Tobin's Q

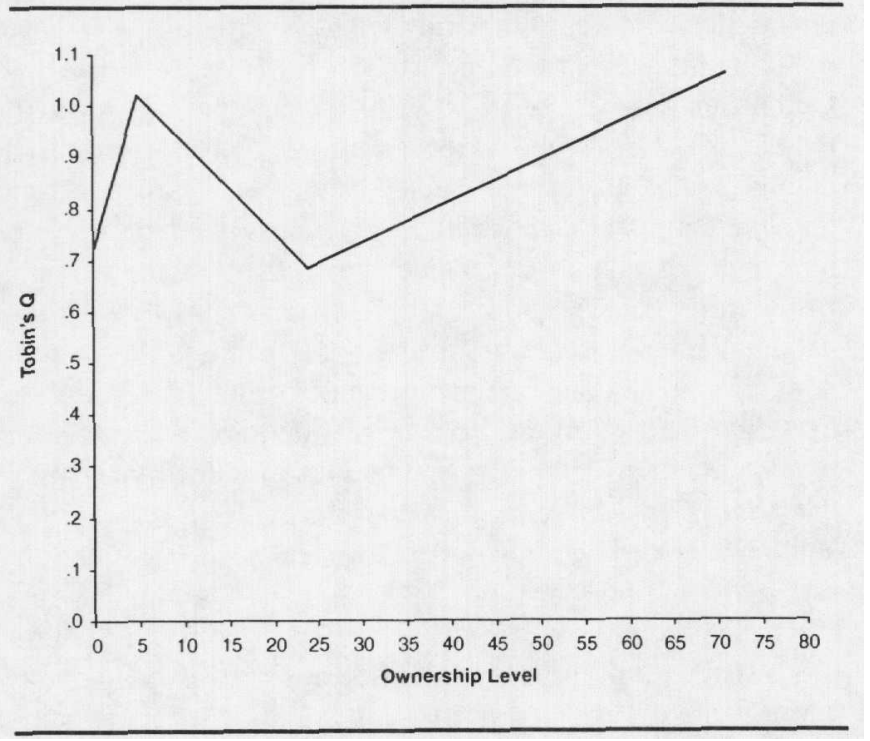

Aaker and Carmon's (1982) and Prasad and Sen's (1999) work is relevant to our research in two ways: First, it is consistent with the general sentiment documented in the finance literature that managers often misuse the discretionary resources under their control. Second, these researchers also suggest that incentive structure can play an important role in contributing toward the observed overadvertising. Following the suggestion of these researchers, we conceptualize how incentive structure (i.e., managerial ownership) affects agency costs and how these costs, in turn, influence the reinvestment of free cash flow into advertising.

\section{Development of Hypothesis and Model}

\section{Background}

Two issues need to be addressed as we set out to develop our research hypothesis. First, do board members influence lower-level tactical decisions such as advertising budgeting? In this regard, we conjecture that though board members are not directly involved in the day-to-day operational decisions of the firm, their motivations strongly influence the behavior of lower-level managers. Such a view is consistent with Fama and Jensen's (1983) observation that lower-level managers initiate (and implement) decisions and board members ratify them. Thus, depending on the level of ownership, lower-level managers learn to submit plans that have more of a convergence-of-interests flavor or an entrenchment flavor. The approved plans are then implemented and go on to affect firm value positively or negatively, depending on the intent behind the plan. We believe that in this way, board members influence various tactical decisions taken by lower-level managers, including the setting of advertising budgets.

The second issue pertains to the relevance of agency costs to board members. Specifically, because board members often belong to other organizations, it may be reasonably argued that their ability to enjoy the benefits of increased firm size is limited. However, there is strong empirical evidence to show that the compensation of board members is significantly influenced by firm size (Hempel and Fay 1994). Thus, the agency problem of expanding the firm beyond the optimal size applies with equal force to board members.

Finally, as we develop our hypothesis, we note that unlike other investments such as factory equipment, real estate purchases, and so forth, the return on advertising is harder to measure. As such, in many situations, good arguments can be made for increasing the advertising budget, irrespective of whether such an increase is warranted. Consequently, our focus on examining the inherent motivations of key decision makers is particularly salient in the context of advertising budgeting.

\section{Hypothesis}

On the basis of the discussion thus far, we posit that managerial ownership will have a systematic impact on the reinvestment of free cash flow into advertising. In effect, we posit that self-interested managers will choose a level of 
reinvestment in advertising that maximizes their private benefits, namely, control and personal remuneration. Consider the impact of ownership at low levels of ownership. Here, entrenchment effects are absent. As ownership increases within this range, managers begin to bear increasingly the cost of inefficient investments; consequently, they will become increasingly circumspect about investing excess cash into advertising. Therefore, in this range, the fraction of discretionary dollars reinvested in advertising will decrease with ownership.

Next, consider the impact of ownership within an intermediate range. Here, increasing levels of ownership give rise to increasing levels of entrenchment. This increasing level of entrenchment, in turn, gives managers the freedom to reinvest excess cash into advertising. In this case, managers recognize that the private benefits from increased firm size exceed their share of the loss in firm value. Consequently, as managers become increasingly entrenched, the fraction of discretionary dollars reinvested in advertising will increase with ownership.

Finally, as ownership increases even further, another effect emerges. By now, managers are fully entrenched and possess considerable freedom with respect to reinvesting excess cash into advertising. Here, however, the relatively high level of managerial ownership begins to put a check on this behavior. In effect, as ownership increases, managers begin to bear fully the cost of reinvesting excess cash into advertising. Moreover, the magnitude of this cost increases with the level of managerial ownership. As such, in this range, the tendency to reinvest excess cash into advertising will again decrease with ownership. ${ }^{6}$

We encapsulate these arguments in the following hypothesis:

$\mathbf{H}_{1}$ : The amount of free cash flow reinvested in advertising will be moderated nonmonotonically by the fraction of management ownership. Specifically, the proportion of free cash flow reinvested in advertising will decrease, then increase, and finally decrease again with the fraction of management ownership.

We note that the postulated nonmonotonic interplay of entrenchment and convergence effects follows directly from Morck, Shleifer, and Vishny's (1988) theoretical and empirical work. This view is also becoming widely accepted by scholars of corporate governance (see, e.g., the review article by Walsh and Seward [1990]). However, its applicability to the advertising budgeting context has not been explored in the literature. Our research efforts aim to redress this gap.

\section{Model}

On the basis of our hypothesis, we present the following model of advertising budgeting:

\footnotetext{
${ }^{6}$ Our arguments here work best when we assume, as suggested in the literature, that increased advertising is not cost effective in that most firms are overadvertising. Although tirms will certainly vary in the degree to which they are overadvertising, it is difficult to describe conditions that will cause this heterogeneity to yield these nonmonotonic effects. In other words, it is unlikely that our hypothesized nonmonotonic effects can be ascribed to this heterogeneity.
}

(1) Advertising = $\beta$ Discretionary Monies $_{-1}[1+$ Agency Costs $]$

$$
+\gamma \mathrm{X}
$$

where the amount of advertising is influenced by the level of discretionary monies with a lag. Moreover, this relationship is moderated by agency costs. In addition, in Equation $1, \mathrm{X}$ is a large vector of covariates representing firm, market, and industry characteristics. It is included for proper specification.

In our empirical work, it is more convenient to work with the following first-difference model:

(2) $\Delta$ Advertising $=\beta \Delta$ Discretionary Monies $_{-1}[1+$ Agency Costs $]$,

where $\Delta$ denotes the first-difference operator with respect to time. In this specification, the coefficients associated with time-invariant covariates, $\gamma$, need not be estimated because they have been differenced out.

\section{Empirical Context, Data, Measures, and Estimation Equation}

\section{Empirical Context}

Because our primary research question pertains to the impact of agency costs in allocating free cash flow, we exclude firms that experience negative earnings (no free cash flow). In addition, we separately analyze firms that experience an increase in earnings across two consecutive periods from those that experience a decrease in earnings across two consecutive periods. We recognize that from an estimation point of view, these firms are identical to firms that experience an increase in earnings. However, it is possible that these latter firms are characterized by somewhat different dynamics. Specifically, to the extent that earnings in the first period serve as a reference point, management may come to view the situation in the second period as one of limited discretionary monies rather than excess discretionary monies. As such, firms that experience an increase in earnings provide us with a better context to examine the impact of agency costs on the allocation of free cash flow. (Subsequently, we also report findings among firms that experience a decrease in earnings.)

Our initial sample is all 10,055 firms described in the Compustat database over the 1990-97 time period (approximately 70,000 firm-year observations). (The Compustat database is a collection of linancial statements gathered from the annual reports and Securities Exchange Commission filings of nearly all publicly traded firms.) In this sample, many firms either have no advertising expenditures or invest too small an amount to report advertising expenditures as a separate line item on their income statements. This causes a majority of firms to drop out of the sample. The extent of management ownership is gathered from the Marketbase database. (The Marketbase database provides a summary of stock ownership by directors and officers of a corporation as reported in filings and proxy statements submitted to the Securities Exchange Commission.) Consistent with our previous discussion, we include only firms that report positive earnings across the two periods. In addition, after reducing 
the sample for the firms that do not report other necessary financial variables or are not covered in the Marketbase database, we are left with 2763 firm-year observations.

\section{Measures}

The measures we use in our empirical work follow directly from the model described in Equation 2. For expositional convenience, we describe our variables over the span of an upcoming period as well as a prior period rather than the span of two previous periods as suggested in Equation 2. The earnings at time $0, \mathrm{E}_{0}$, report the earnings for the period just ended. ${ }^{7}$ The earnings at time $-1, \mathrm{E}_{-1}$, report the earnings for the previous period. We use the difference between these two amounts, $E_{0}-E_{-1}$, as our measure for $\Delta$ Discretionary Monies. We label this key measure CHG EARN. The dependent variable is the change in the advertising budget between the period just ended, $\mathrm{A}_{0}$, and the upcoming period, $A_{1}$. Our dependent variable is thus $A_{1}-A_{0}$, and we label it CHG ADV.

With respect to management ownership, we follow Morck, Shleifer, and Vishny (1988) and construct the following variable (ownership refers to ownership by the top management team, i.e., board members):

$$
\begin{aligned}
\text { OWNERSHIP LOW } & =\text { ownership }, \text { if ownership }<.05 \\
& =.05, \text { if ownership } \geq .05
\end{aligned}
$$

OWNERSHIP MED $=0$, if management ownership $<.05$

$$
\begin{aligned}
& =\text { ownership }-.05, \text { if } .05 \leq \text { ownership }<.25 \\
& =.20 \text {, if ownership } \geq .25
\end{aligned}
$$

OWNERSHIP HIGH $=0$, if ownership $<.25$

$$
=\text { ownership }-.25 \text {, if ownership } \geq .25
$$

We use boundaries of .05 and .25 because they emerge in Morck, Shleifer, and Vishny's (1988) empirical investigation. However, as these authors themselves point out, the exact cutoff points are nebulous because the extent of entrenchment is not likely to be perfectly correlated with ownership. Some management teams, by virtue of their tenure with the firm or status as founding family, may become entrenched with relatively small stakes. Moreover, although higher ownership will typically lead to deeper entrenchment, diminishing returns may set in well before $50 \%$ is reached. These arguments notwithstanding, the sensitivity analysis conducted by Morck, Shleifer, and Vishny convinces us that the aforementioned boundaries are appropriate for empirical work. ${ }^{8}$

\footnotetext{
7Earnings are frequently used to represent discretionary monies. We use EBITDA, that is, earnings before interest, taxes, depreciation, and amortization. This measure is widely used in accounting and finance studies.

${ }^{8}$ Subsequently, we also discuss sensitivity analysis pertaining to these boundaries.
}

\section{Estimation Equation}

In straightforward fashion, we use the following equation to investigate the effects we seek: ${ }^{9}$

$$
\text { (3) } \begin{aligned}
\text { CHG ADV } & =\beta_{0}+\beta_{1} \text { CHG EARN } \\
& +\beta_{2} \text { CHG EARN } \times \text { OWNERSHIP LOW } \\
& +\beta_{3} \text { CHG EARN } \times \text { OWNERSHIP MED } \\
& +\beta_{4} \text { CHG EARN } \times \text { OWNERSHIP HIGH. }
\end{aligned}
$$

\section{Findings}

We organize our findings into three main parts. We first describe our sample characteristics. We then present our main findings. This is followed by additional evidence that supports the notion that our observed effects are not driven by omitted variables. Finally, we report findings pertaining to sensitivity analysis and present alternative specifications of our basic model to demonstrate the robustness of our findings.

\section{Sample Characteristics}

Here, we report sample characteristics for the 2763 firms that enjoy an increase in earnings across two consecutive periods. In our sample, the mean change in earnings is $\$ 15.42$ million, and it varies from 0 to $\$ 944$ million. Despite an increase in earnings, firms chose to decrease their advertising budgets in $780(28.2 \%)$ cases. In the remaining 1983 cases, firms increased their advertising budgets. The mean change in advertising is $\$ 2.61$ million. It varies from $-\$ 97.70$ million to $\$ 335.75$ million.

Figure 3 displays the distribution of management ownership in our sample. The distribution slopes downward as the level of ownership increases. The mean level of ownership on our sample is .30 , with standard deviation 22 .

Table 1 presents the simple correlation matrix for our analysis variables. We find that CHG EARN and the three interaction terms associated with CHG EARN are all positively and significantly correlated with $\mathrm{CHG}$ ADV. As expected, there is a significant, positive correlation between CHG EARN and the three interaction terms associated with this variable. Indeed, two of these three correlations exceed 50. Moreover, there is a statistically significant, positive correlation within the three interaction terms associated with CHG EARN; two of the three correlations exceed .50 .

\footnotetext{
${ }^{9}$ Our measures and specification described in Equation 3 are statistically equivalent to the standard specification recommended to estimate piecewise linear regressions (see, e.g., Neter, Wasserman, and Kutner 1985 , p. 348). The standard specification would suggest the following four variables: CHG EARN, CHG EARN $\times$ Ownership, CHG EARN $\times($ Ownership -.05$) \times$ Dummy 1 , and CHG EARN $\times($ Ownership -.25$) \times$ Dummy 2 . Here, Dummy $1=$ 1 if Ownership > .05, 0 otherwise; Dummy $2=1$ if Ownership > $.25,0$ otherwise. This latter specification, however, would require us to collect coefficients to represent the impact of ownership in the $[.05, .25]$ and $[.25,1.00]$ intervals; consequent $y$, for expositional convenience, we follow the measures and specitication described in Equation 3.
} 
Finally, because we include sales in a variant of our basic model, we also report correlations between change in sales (CHG SALES) and the remaining variables. We find that CHG SALES is positively and significantly correlated with CHG ADV, CHG EARN, and the three interaction terms associated with CHG EARN.

We also find that the advertising-to-sales ratio has a mean of $3.82 \%$ and a median of $2.06 \%$. More important, the advertising-to-earnings ratio has a mean of $47.12 \%$ and

FIGURE 3

\section{Distribution of Managerial Ownership in the} Sample

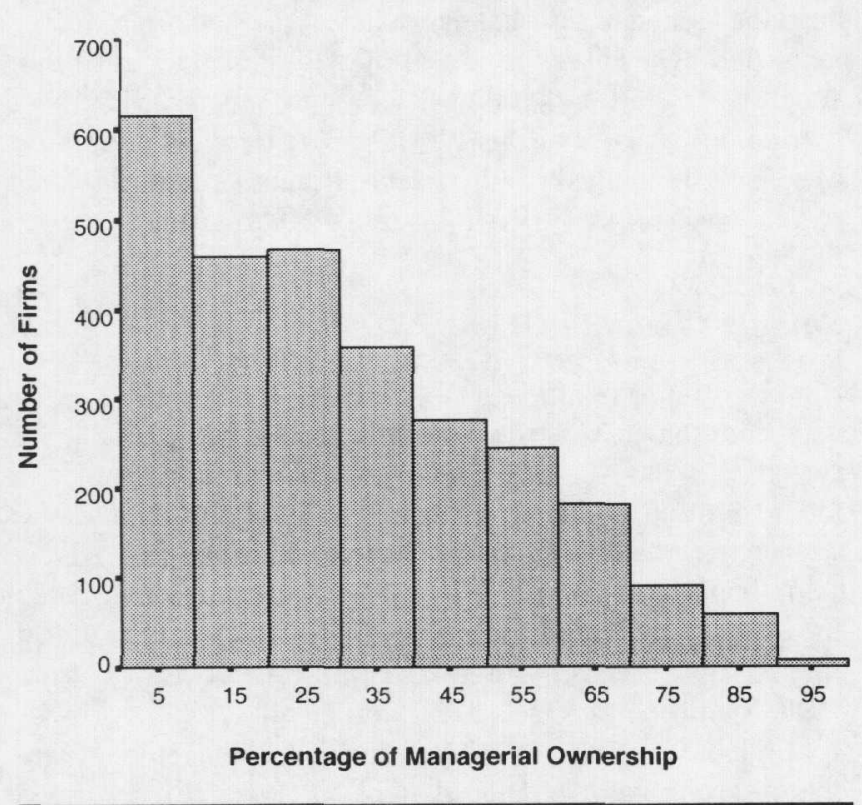

a median of $16.75 \%$. This last finding suggests that advertising budgets are a large enough proportion of earnings that they will warrant scrutiny and ratification by the board.

\section{Findings}

We use ordinary least squares to estimate the model described in Equation 3, and the results are displayed in Table 2 (Model 1). The results reveal that the overall model is highly significant $\left(p<.0000\right.$ ), with an adjusted $\mathrm{R}^{2}$ of .40 . All coefficients have the expected sign and are significant at the .01 level. We find that changes in the level of earnings have a significant impact on the advertising budget for the upcoming period. On average, for a firm with no management ownership, a substantial amount of each discretionary dollar, namely, $\$ .262$, is reinvested in advertising. This level of reinvestment in advertising, expressed as a fraction of advertising in the current period, can be fairly substantial. Specifically, the median reinvestment is approximately $28.2 \%$ of the current advertising budget. We are quick to point out, however, that this large reinvestment need not indicate the use of the affordability heuristic. It could simply be a manifestation of the percentage of sales method advocated by Nerlove and Arrow (1962) or the insurance argument discussed previously.

In contrast, our findings with respect to the three interaction terms can potentially shed light on the impact of agency costs in allocating discretionary monies. The coefficient associated with OWNERSHIP LOW is negative and statistically significant, which implies that in the $0 \%-5 \%$ ownership range, each percentage point of management ownership reduces the amount of the discretionary dollar reinvested in advertising by $\$ .0612$. This finding reveals that as managers begin to bear the cost of advertising, they

TABLE 1

Correlation Matrix of Variables $(n=2763)$

\begin{tabular}{|c|c|c|c|c|c|c|}
\hline & $\begin{array}{l}\text { CHG } \\
\text { ADV }\end{array}$ & $\begin{array}{l}\text { CHG } \\
\text { EARN }\end{array}$ & $\begin{array}{l}\text { CHG } \\
\text { EARN } \times \\
\text { OWNERSHIP } \\
\text { LOW }\end{array}$ & $\begin{array}{c}\text { CHG } \\
\text { EARN } \times \\
\text { OWNERSHIP } \\
\text { MEDIUM }\end{array}$ & $\begin{array}{c}\text { CHG } \\
\text { EARN } \times \\
\text { OWNERSHIP } \\
\text { HIGH }\end{array}$ & $\begin{array}{c}\text { CHG } \\
\text { SALES } \\
\end{array}$ \\
\hline CHG ADV & 1.00 & & & & & \\
\hline CHG EARN & $\begin{array}{c}.53 \\
(.00)\end{array}$ & 1.00 & & & & \\
\hline $\begin{array}{l}\text { CHG EARN } \times \\
\text { OWNERSHIP } \\
\text { LOW }\end{array}$ & $\begin{array}{c}.24 \\
(.00)\end{array}$ & $\begin{array}{c}.76 \\
(.00)\end{array}$ & 1.00 & & & \\
\hline $\begin{array}{l}\text { CHG EARN } \times \\
\text { OWNERSHIP } \\
\text { MEDIUM }\end{array}$ & $\begin{array}{c}.24 \\
(.00)\end{array}$ & $\begin{array}{c}.52 \\
(.00)\end{array}$ & $\begin{array}{c}.78 \\
(.00)\end{array}$ & 1.00 & & \\
\hline $\begin{array}{l}\text { CHG EARN } \times \\
\text { OWNERSHIP } \\
\text { HIGH }\end{array}$ & $\begin{array}{c}.08 \\
(.00)\end{array}$ & $\begin{array}{c}.19 \\
(.00)\end{array}$ & $\begin{array}{c}.30 \\
(.00)\end{array}$ & $\begin{array}{c}.54 \\
(.00)\end{array}$ & 1.00 & \\
\hline CHG SALES & $\begin{array}{l}.47 \\
(.00)\end{array}$ & $\begin{array}{c}.70 \\
(.00)\end{array}$ & $\begin{array}{c}.63 \\
(.00)\end{array}$ & $\begin{array}{l}.57 \\
(.00)\end{array}$ & $\begin{array}{l}.15 \\
(.00)\end{array}$ & $\begin{array}{l}1.00 \\
(.00)\end{array}$ \\
\hline
\end{tabular}

Notes: All correlations are significant at the $p<.01$ level. 
TABLE 2

Regression Results (Dependent Variable: Change in Advertising; Analysis Restricted to Increases in Earnings)

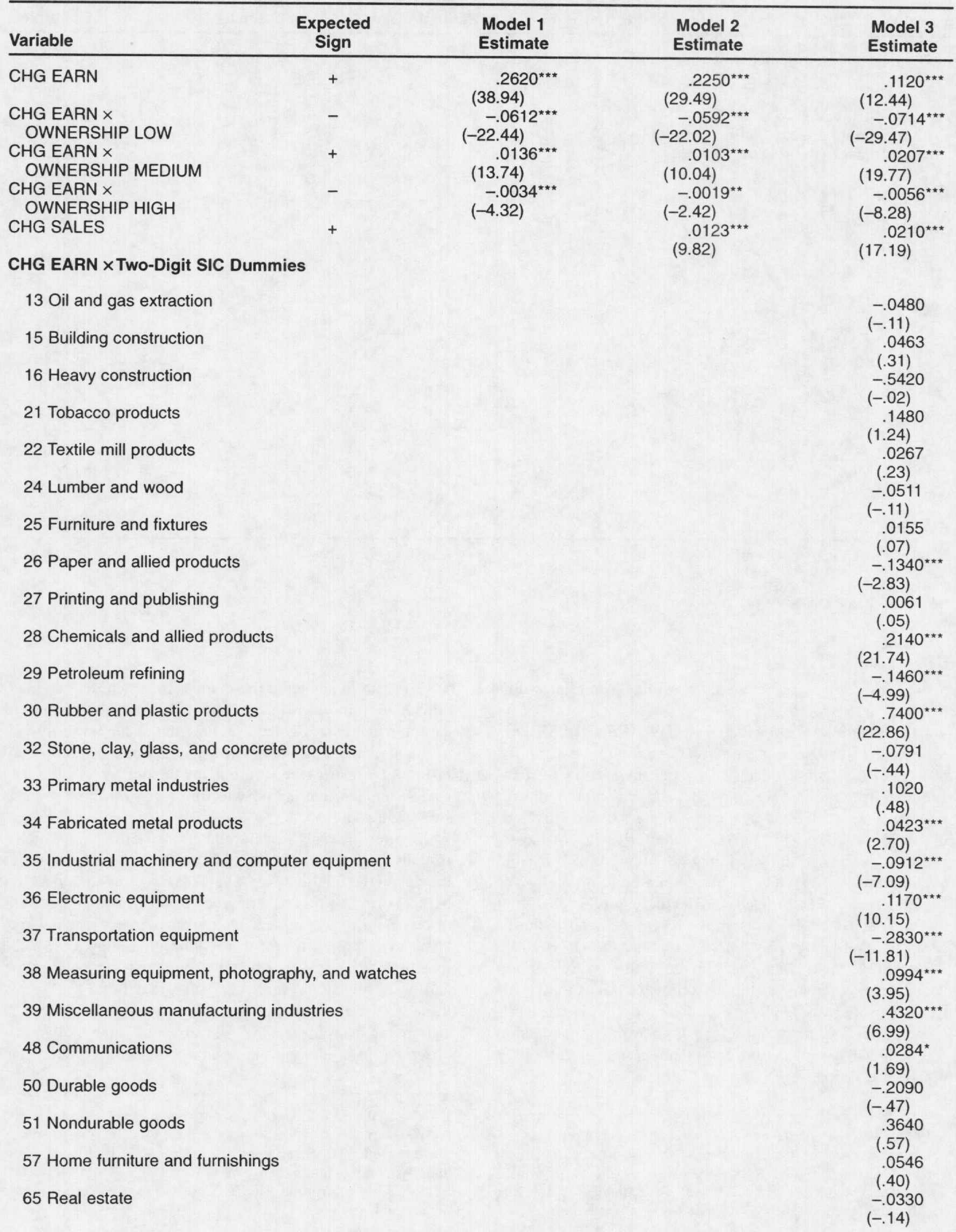


TABLE 2

Continued

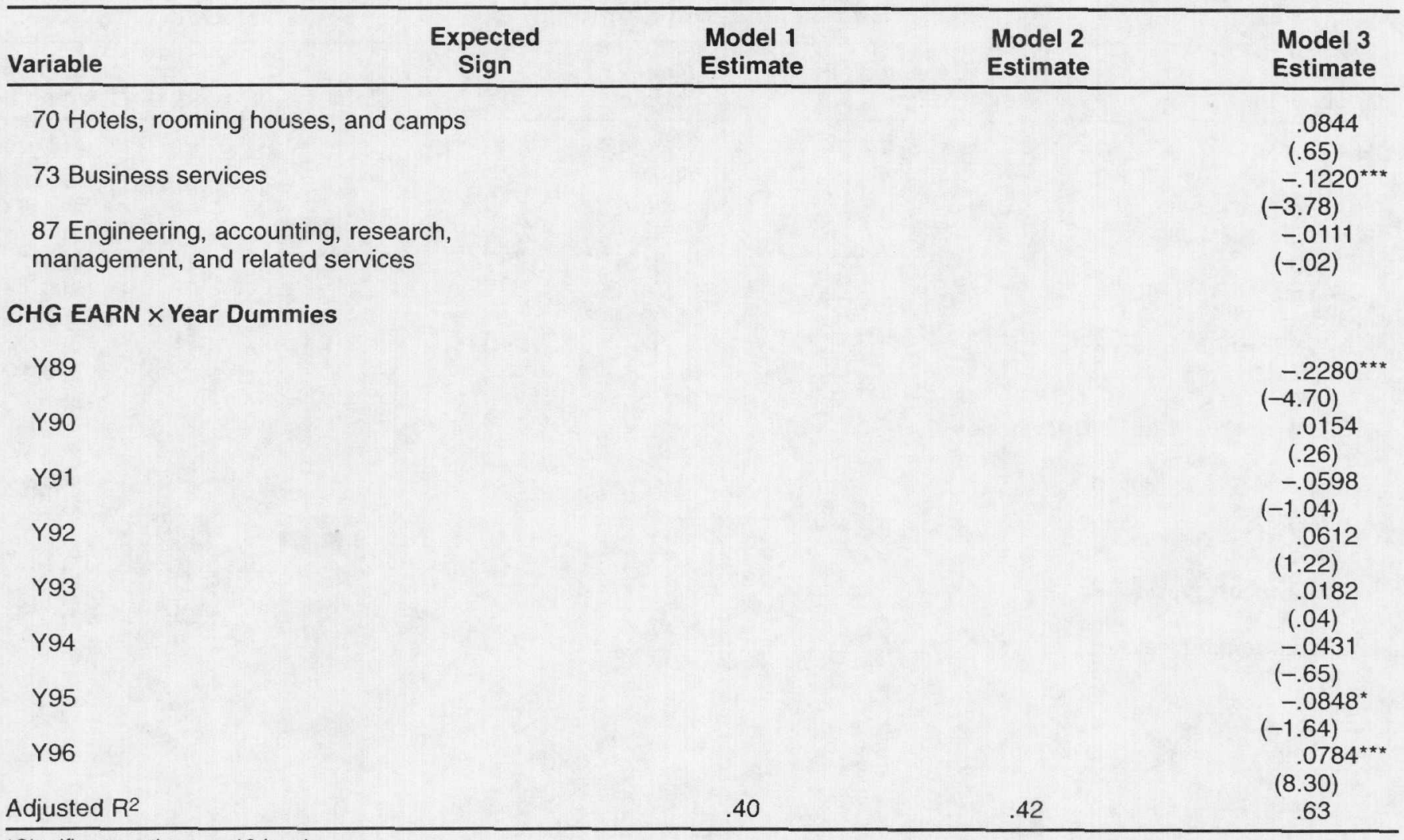

*Significant at the $p<.10$ level.

** Significant at the $p<.05$ level.

***Significant at the $p<.01$ level.

Notes: $n=2763 ; t$-statistics are in parentheses.

become more circumspect about investing discretionary dollars back into advertising.

The coefficient associated with OWNERSHIP MED is positive and statistically significant, implying that in the $5 \%-25 \%$ ownership range, each percentage point of management ownership increases the amount of the discretionary dollar reinvested in advertising by $\$ .0136$. This finding is consistent with our conjecture that as managers become entrenched, they will begin to pump up advertising expenditures with a view toward empire building.

Finally, as hypothesized, the coefficient associated with OWNERSHIP HIGH is negative and statistically significant. Economically, this implies that in the $25 \%-100 \%$ ownership range, each percentage point in ownership decreases the amount of the discretionary dollar reinvested in advertising by $\$ .0034$. As expected, this change in investment policy occurs because the high level of ownership causes managers to become careful about how discretionary dollars are allocated. 10

\footnotetext{
${ }^{10}$ Recall that the partial correlation matrix reveals a positive correlation between the three interaction terms and our dependent variable, $\mathrm{CHG} A \mathrm{ADV}$. Here, however, we describe two negative coefficients and one positive coefficient. To reconcile this, note that the three interaction terms are all positively correlated with CHG
}

To better understand the manner in which discretionary dollars are reinvested in advertising, we plot the fraction of earnings that is reinvested as a function of the level of management ownership. We obtain this graph in straightforward fashion by using the coefficients associated with CHG EARN and its interaction with the three ownership terms (see Figure 4).

Figure 4 reveals the aforementioned effects pictorially. Initially, management ownership has a strong negative impact on the fraction of earnings that is reinvested in advertising. However, this pattern reverses for intermediate levels of ownership and reverses again as ownership reaches high levels. The proportion of discretionary earnings reinvested in advertising is approximately similar at zero ownership and at an ownership level of approximately $25 \%$. At both these levels, about one-quarter of each discretionary dollar is reinvested in advertising. Because this latter maxima is observed in a domain in which both convergence and

EARN. CHG EARN, in turn, is positively correlated with $\mathrm{CHG}$ ADV. Therefore, it is likely that the positive correlation between the three interaction variables and $\mathrm{CHG} A \mathrm{ADV}$ is driven by the underlying association between CHG EARN and CHG ADV. Indeed, after controlling for CHG EARN in the regression, we obtain the hypothesized effects. 


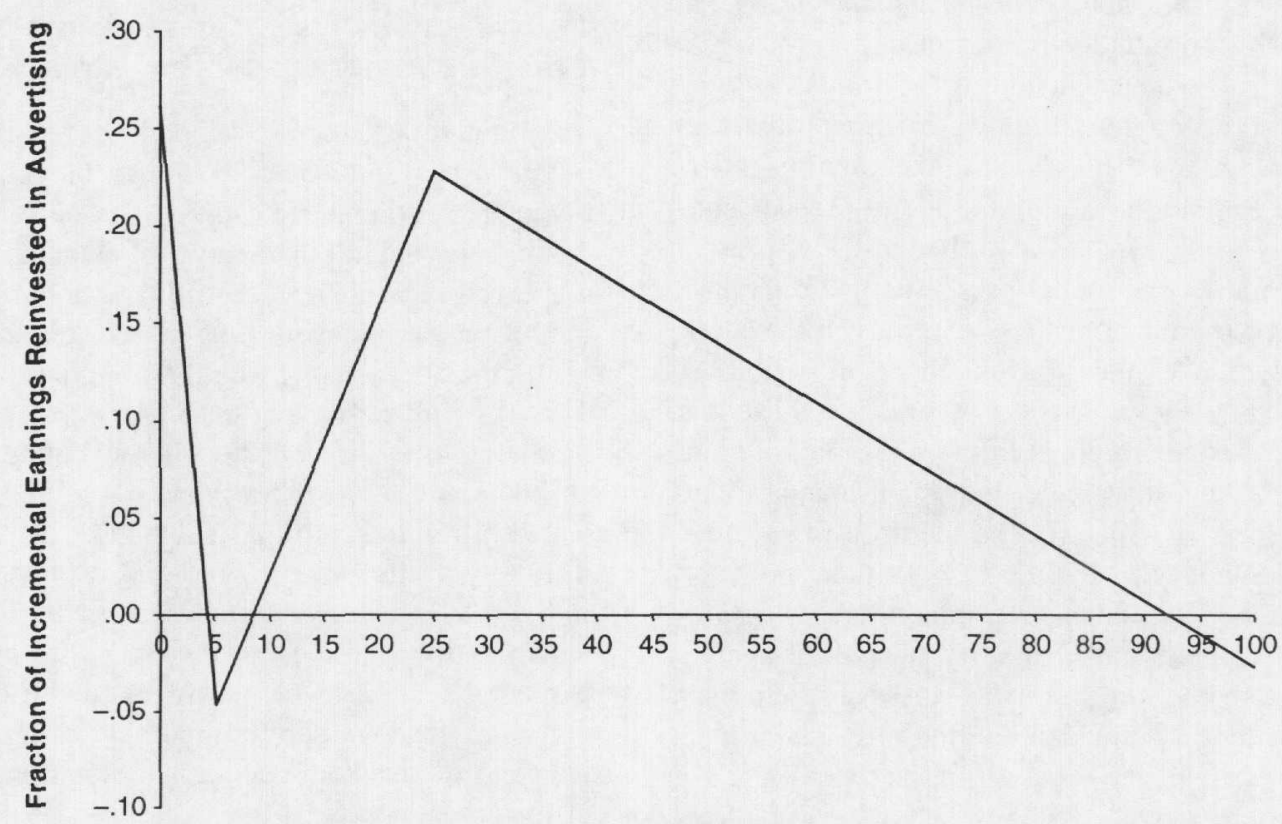

Ownership Level

entrenchment effects are at work, it is obvious that the reinvestment due to entrenchment alone is larger than the reinvestment arising at a firm with zero managerial ownership (i.e., no convergence or entrenchment effects): Thus, the singular impact of entrenchment can be fairly substantial.

Overall, our findings are consistent with the postulated interplay between convergence and entrenchment effects: The reinvestment in advertising varies nonmonotonically as the level of managerial ownership increases. Specifically, managers who are entrenched spend a greater proportion of discretionary dollars on advertising than do managers who are effectively disciplined by the market or managers who bear the full cost of advertising expenditures.

Next, we run a second regression in which we include the change in sales as a potential control variable. In effect, we use the difference in sales at time $0, \mathrm{~S}_{0}$, and time $-1, \mathrm{~S}_{-1}$, to account for the conjecture that some firms may be influenced by the level of previous sales in setting their advertising budgets. Given our first-difference specification, we label this variable, $S_{0}-S_{-1}$, as CHG SALES. The results including this variable are displayed in Table 2 (Model 2).

This model has an adjusted $\mathrm{R}^{2}$ of .42 , an improvement of only about 2 percentage points over the previous model. As before, all coefficients have the expected signs and are statistically significant. Here, we find that only a relatively small amount, namely, $\$ .0123$, is reinvested in advertising per dollar of sales increase. Overall, this set of findings suggests that CHG SALES is not as salient as CHG EARN in the advertising budgeting process. These findings further justify our focus on the role of earnings in explaining changes in advertising budgets.
Finally, recognizing that there may be considerable heterogeneity across industries in the fraction of earnings that is reinvested in advertising, we extend our basic model by including interaction terms for each industry. Following the work of Chauvin and Hirschey (1993) on advertising expenditures, we employ two-digit Standard Industrial Classification (SIC) codes to serve as our proxy for industry dummies. We also include dummies for the different years to account for structural changes that may have occurred over time. These results are also reported in Table 2 (Model 3). Although specifying expected signs by industry is outside the scope of this article, we do find industry-specific effects: The overall $\mathrm{R}^{2}$ for the model increases to .63 . Moreover, of a total of 28 industries, $" 12$ of the SIC $\times$ CHG EARN terms are statistically significant. In addition, three of the Year $\times$ CHG EARN are significant, implying structural changes over time. Our main findings remain unchanged from both a statistical and a substantive point of view. These findings give us confidence that our observed effects are not being driven by differences in advertising budgeting practices across industries and time.

\section{Omitted Variable Bias}

Here, we allow for the possibility that our estimation equation is incompletely specified and our findings are driven by

\footnotetext{
"Any SIC codes with few firms are lumped into an "other" category. This is the category that is excluded in the estimation equation.
} 
excluded variables. Although such a conjecture is indeed reasonable for any model, it is less of a concern for our model for two reasons: First, the interaction terms are hypothesized to vary in a nonmonotonic manner. As such, any bias arising from omitted variables must also vary in a systematic manner to render our findings spurious. Second, our first-difference specification alleviates this problem to some extent (see, e.g., the discussion of this point by Anderson, Banker, and Ravindran [2000] and the references contained therein). Nevertheless, as a further test, we present results from estimating the model presented in Equation 3 among firms that experience positive earnings in two periods but have a lower level of earnings in the latter period. As mentioned previously, these firms are identical to those that experience an increase in earnings from an estimation point of view. However, they differ in an important manner from a behavioral perspective. Specifically, the drop in earnings may cause management to view the firm's situation as one of limited discretionary monies rather than excess discretionary monies. Consequently, the hypothesized agency effects pertaining to the allocation of excess discretionary monies should be less pronounced within this domain.

Accordingly, we analyze 1141 firms that experience a decrease in earnings across two consecutive periods. Surprisingly, in this subsample, $646(56.6 \%)$ increased their advertising budget despite the decrease in earnings. The remaining 495 decreased their advertising budget as a result of depressed earnings. As before, we use ordinary least squares to estimate a model with $\mathrm{CHG}$ ADV as the dependent variable and CHG EARN and its interaction with management ownership as the independent variables. The results are displayed in Table 3.

Table 3 reveals that the model has much lower explanatory power in this domain $\left(\mathrm{R}^{2}=.02\right)$. If our previous findings were indeed being driven by omitted variables, we would have observed a comparable role for these variables in this domain. This is not the case here. Moreover, three of four coefficients are statistically significant, but with signs opposite from those expected. Overall, these findings suggest that perceptions of excess cash flow are driven by both the presence of positive earnings and the trend in earnings.
In any case, these findings weaken the argument that our observed effects are being driven by an omitted variable bias.

\section{Sensitivity Analysis: Cutoff Points and Construction of Ownership Variable}

To examine whether our model is sensitive to the cutoff points used for ownership and/or our construction of the ownership variable, we estimate our basic model employing a cubic polynomial in the level of ownership. The results are displayed in Table 4. Compared with our basic model, this model has a somewhat lower fit: The adjusted $\mathrm{R}^{2}$ is .36 . Using the coefficients, we plot the reinvestment graphically. This is displayed in Figure 5. We find a similar pattern of nonmonotonic effects, though the boundaries seem to be shifted somewhat to the right to $13 \%$ and $57 \%$. This rightward shift in the cutoff points may be driven, in part, by the difficulty of the cubic polynomial to change direction. Similarly, the large negative reinvestment at high levels of ownership is likely driven by the fact that the cubic function explodes at high levels of its argument. Overall, however, our main message of nonmonotonic effects prevails, though we concede that some doubt is cast about the exact location of the cutoff points.

\section{Alternative Specifications}

We also run a basic model with change in earnings modified by the logarithm and square root transformation. In both cases, all independent variables continue to be statistically significant. The adjusted $\mathrm{R}^{2}$, however, drops to $15 \%$ and $30 \%$, respectively. Overall, these transformations do not affect the substantive impact of our empirical findings.

\section{Contributions, Limitations, and Conclusions}

Despite large monetary outlays, advertising budgeting is a poorly understood topic. Research conducted over a period of two decades suggests that the vast majority of firms are overadvertising (Aaker and Carman 1982; Prasad and Sen 1999). Moreover, empirical surveys report that practitioners

TABLE 3

Regression Results (Dependent Variable: Change in Advertising; Analysis Restricted to Decreases in Earnings)

\begin{tabular}{|c|c|c|}
\hline Variable & Expected Sign & Estimate \\
\hline CHG EARN & + & $\begin{array}{l}-.0819^{\star \star} \\
(-5.18)\end{array}$ \\
\hline CHG EARN $\times$ OWNERSHIP LOW & - & $\begin{array}{l}.0505^{* *} \\
(2.77)\end{array}$ \\
\hline CHG EARN $\times$ OWNERSHIP MEDIUM & + & $\begin{array}{l}-.0148^{*} \\
(-2.38)\end{array}$ \\
\hline CHG EARN $\times$ OWNERSHIP HIGH & - & $\begin{array}{l}.0016 \\
(.98)\end{array}$ \\
\hline Adjusted $\mathrm{R}^{2}$ & .02 & \\
\hline
\end{tabular}

*Significant at the $p<.05$ level.

**Significant at the $p<.01$ level.

Notes: $n=1141$; $t$-statistics are in parentheses. 
TABLE 4

Regression Results (Dependent Variable: Change in Advertising; Cubic in Ownership)

\begin{tabular}{lcc}
\hline Variable & Expected Sign & Estimate \\
\hline CHG EARN & + & $.2020^{*}$ \\
CHG EARN $\times$ OWNERSHIP & - & $(35.78)$ \\
CHG EARN $\times$ OWNERSHIP SQUARE & $-.0029^{*}$ \\
CHG EARN $\times$ OWNERSHIP CUBE & + & $(-4.36)$ \\
Adjusted R 2 & $-00002841^{*}$ \\
\hline
\end{tabular}

*Significant at the $p<.01$ level.

Notes: $n=2763$; $t$-statistics are in parentheses.

FIGURE 5

Fraction of Earnings Reinvested in Advertising as a Function of Ownership Level (Cubic Specification)

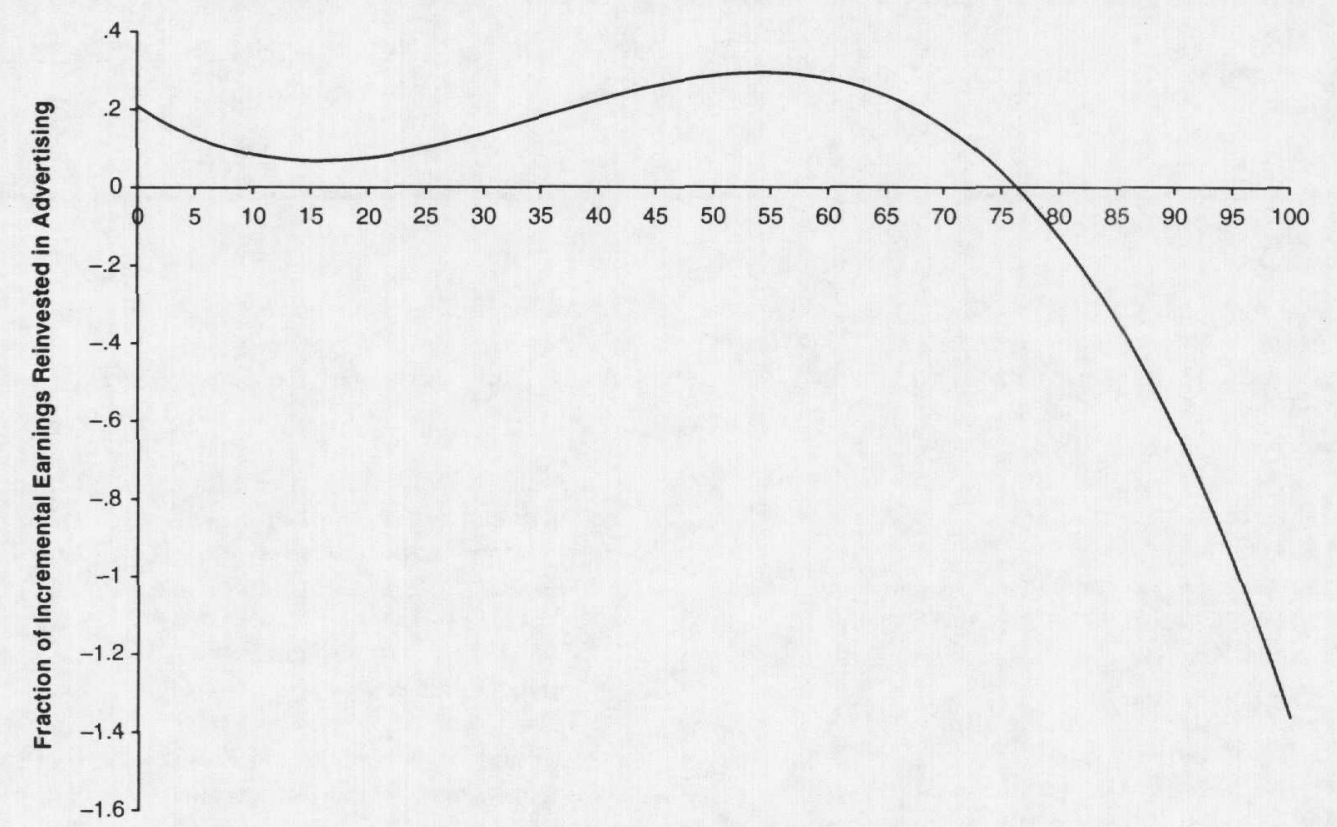

Ownership Level

frequently employ heuristics such as the affordability method in setting their advertising budgets (Tellis 1998). Given this state of affairs, it is not surprising that marketing scholars have highlighted the need for additional research on the topic of advertising budgeting. In addition, an area often identified for further research is the impact of the incentive structure on advertising budgeting decisions (Prasad and Sen 1999). This research responds to these calls, from both a theoretical and an empirical perspective.

Following research in the finance literature, we first show that the impact of the incentive structure on the advertising budgeting decision is complex. Specifically, a key incentive tool, namely, managerial ownership, predicts a nonmonotonic effect on the use of the affordability method. In particular, managerial ownership gives rise to a mix of convergence and entrenchment effects. Therefore, as owner- ship increases from $0 \%$ to $100 \%$, we hypothesize that selfinterested managers will first decrease, then increase, and finally decrease their propensity to reinvest excess cash into advertising. The identification of such nonmonotonic effects within the advertising context is an important theoretical contribution of our work.

Empirically, we find that the fraction of discretionary dollars reinvested in advertising varies systematically with the level of managerial ownership. These findings are noteworthy because they uncover a hitherto undocumented relationship, namely, that of a nonmonotonic relationship between the use of the affordability heuristic and the level of managerial ownership. This finding, coupled with those reported in the accounting and finance literature, paves the way toward an empirical generalization that would link agency costs and the allocation of discretionary monies in a 
wide variety of settings. This second contribution of our work is also important because, as Bass and Wind (1995) note, empirical generalizations are the building blocks of science.

Finally, our findings provide an explicit manifestation of the theory documented by Morck, Shleifer, and Vishny (1988). Although these researchers convincingly demonstrate that firm value varies nonmonotonically with ownership levels, our study suggests one route by which this relationship might come about. Specifically, our empirical findings suggest that entrenched managers tend to dissipate firm value by overspending on advertising. This identification of a specific mechanism by which firm value is dissipated is important in its own right. It also underscores the importance of marketing resource allocation decisions in influencing firm value. These insights constitute a third contribution of our research.

Our work also offers specific managerial implications. In particular, our findings suggest that one way to enhance the advertising budgeting process is to redesign the reward structure so as to bring about greater goal alignment between managers and owners. In scenarios in which it is difficult to bring about goal alignment through the right level of managerial ownership, our research informs stakeholders that they need to institute alternative mechanisms to govern the advertising budgeting process. Our research also informs key decision makers that such scenarios are likely to occur for intermediate levels of managerial ownership.

Our research is not without limitations. Given the aggregate level of data we analyze, we are unable to verify with certainty if our observed effects are indeed being driven by the micro-level processes that we suggest. In other words, although our data are consistent with a view in which the motivations of board members are ultimately injected into the advertising budgeting decisions of various divisions of the firm, we are unable to establish that this is indeed the process. There is a need for additional research, conducted perhaps with qualitative techniques, that will provide a deeper understanding of the relationship among free cash flow, agency costs, and the affordability method of advertising budgeting. We hope our research will stimulate such efforts.

\section{REFERENCES}

Aaker, David A. and James A. Carman (1982), "Are You Overadvertising?" Journal of Advertising Research, 22 (4), 57-70.

Anderson. Mark C., Rajiv D. Banker, and Sury Ravindran (2000), "Executive Compensation in the Information Technology Industry," Management Science, 46 (4), 530-47.

Bass, Frank and Jerry Wind (1995), "Introduction to the Special Issue: Empirical Generalizations in Marketing," Marketing Science, 14 (3:2), GI-G5

Bergen. Mark, Shantanu Dutta, and Orville C. Walker (1992), "Agency Relationships in Marketing: A Review and Implications of Agency and Related Theories," Journal of Marketing, $56(3), 1-24$.

Bigne. J. Enrique (1995), "Advertising Budget Practices: A Review," Journal of Current Issues and Research in Advertising, $17(2) .17-31$.

Chauvin, Keith W. and Mark Hirschey (1993), "Advertising, R\&D Expenditures, and the Market Value of the Firm," Financial Management, 22 (4), 128-40.

Czinkota. Michael R. (1999), Marketing Best Practices. Fort Worth, TX: Dryden Press

Demsetz. H. (1983), "The Structure of Ownership and the Theory of the Firm." Journal of Law and Economics, 26 (2), 375-90.

Eastlack. Joseph O. and Ambar G. Rao (1989), "Advertising Experiments at the Campbell Soup Company," Marketing Science. 8 (Winter), 57-71.

Fama, Eugene F. (1980), "Agency Problems and Theory of the Firm," Journal of Political Economy, 88 (2), 288-307.

_ and Michael C. Jensen (1983), "Separation of Ownership and Control," Journal of Law and Economics, 26 (2), 301-25.

Gibbs. Philip A. (1993), "Determinants of Corporate Restructuring: The Relative Importance of Corporate Governance, Takeover Threat, and Free Cash Flow," Strategic Management Journal, 14 (Summer), 51-68.

Griffin, James M. (1988), "A Test of the Free Cash Flow Hypothesis." Review of Economics and Statistics, 70 (1), 76-82.

Gul, Ferdinand A. and Judy S.L. Tsui (1998), "A Test of the Free Cash Flow and Debt Monitoring Hypotheses: Evidence from
Audit Pricing," Journal of Accounting and Economics, 24 (2), 219-37.

Gupta, Atul and Leonard Rosenthal (1991), "Ownership Structure, Leverage, and Firm Value: The Case of Leveraged Recapitalizations," Financial Management, 20 (3), 69-83.

Hart, Oliver D. (1983), "The Market Mechanism as an Incentive Scheme," Bell Journal of Economics, 14 (2), 366-82.

Hempel, Paul and Charles Fay (1994), "Outside Director Compensation and Firm Performance," Human Resource Management, $33(1), 111-33$.

Jensen. M.C. (1986), "Agency Costs of Free Cash Flow, Corporate Finance, and Takeovers," American Economic Review, 76 (2). $323-39$

- and W.H. Meckling (1976), "Theory of the Firm: Managerial Behavior, Agency Costs, and Ownership Structure," Journal of Financial Economics, 3 (4), 305-60.

- and (1992), "Specific and General Knowledge, and Organizational Structure," Journal of Applied Corporate Finance, 8 (2), 4-18

and R. Ruback (1983), "The Market for Corporate Control: The Scientific Evidence," Journal of Financial Economics, 11 (1), 5-50.

Lehn, Kenneth and Annette Poulsen (1989). "Free Cash Flow and Stockholder Gains in Going Private Transactions," Journal of Finance, 44 (3), 771-87.

Loh, Lawrence (1992), "Financial Characteristics of Leveraged Buyouts," Journal of Business Research, 24 (3), 241-52.

Mann, Steven V. and Neil W. Sicherman (1991), "The Agency Costs of Free Cash Flow: Acquisition Activity and Equity Issues," Journal of Business, 64 (2), 213-27.

Moore, William T., Donald G. Christensen, and Rodney L. Roenfeldt (1989), "Equity Valuation Effects of Forming Master Limited Partnerships," Journal of Financial Economics, 24 (1). 107-24.

Morck, Randall, Andrei Shleifer, and Robert W. Vishny (1988), "Management Ownership and Market Valuation: An Empirical Analysis," Journal of Financial Economics, 20 (1), 293-315. 
Nerlove, Marc and Kenneth J. Arrow (1962), "Optimal Advertising Policy Under Dynamic Conditions," Economica, 29 (May), $129-42$.

Neter, John, William Wasserman, and Michael H. Kutner (1985), Applied Linear Statistical Models. Homewood, IL: Richard D. Irwin.

Prasad, Arbind and Subrata Sen (1999), "Are Firms Advertising Too Much?" paper presented at the Marketing Science Conference, Syracuse University (May).

Tellis, Gerard J. (1998), Advertising and Sales Promotion Strategy. Reading, MA: Addison-Wesley.
Walsh, James and James K. Seward (1990), "On the Efficiency of Internal and External Corporate Control," Academy of Management Review, 15 (3), 421-58.

Wells, Brenda P., Larry A. Cox, and Kenneth M. Gaver (1995), "Free Cash Flow in the Life Insurance Industry," Journal of Risk and Insurance, 62 (1), 50-66.

Wernerfelt, B. and C.A. Montgomery (1988), "Tobin's Q and the Importance of Focus in Firm Performance," American Economic Review, 78 (1), 246-50.

Weston, J.F. (1979), "The Tender Takeover," Mergers and Acquisitions, 13 (1), 74-82. 